\title{
PARAMETERS OF METABOLIC SYNDROME IN OBESE CHILDREN AND ADOLESCENTS
}

\author{
Marko Kostovski $^{1}$, Zoran Gucev ${ }^{1}$, Velibor Tasic ${ }^{1}$, Momir Polenakovic ${ }^{2}$ \\ ${ }^{1}$ Medical Faculty Skopje, Republic of Macedonia \\ ${ }^{2}$ Macedonian Academy of Science and Arts, Skopje, Republic of Macedonia
}

Corresponding author: Marko Kostovski, Medical Faculty Skopje, R. Macedonia, Mother Teresa 171000 Skopje, Republic of Macedonia, E-mail: marko.kostovski@medf.ukim.edu.mk

\section{ABSTRACT}

Background: Obesity is the most common chronic metabolic disease in children and adolescents. It has reached epidemic ranges and is a significant global problem.

Objective: This study aimed to investigate the possible metabolic disturbances in children and adolescents with obesity and severe obesity.

Subjects and methods: This cross-sectional study included 158 ( 82 boys, 76 girls) obese children and adolescents between ages of 0 and 17 years $(10.43 \pm 3.11$ years $)$. The obesity was defined according to the sex- and age- specific growth charts proposed by the Centers for Disease Control and Prevention as BMI $\geq 95$ th percentile. Severe obesity was classified as $120 \%$ of the 95 th percentile for age and sex. Study participants underwent medical assessment and analysis of: ALT, AST, fasting serum triglycerides, total serum cholesterol, fasting plasma glucose and plasma glucose from oral glucose tolerance test.

Results: The majority of study participants were severely obese $(69.92 \%)$. The highest distribution of abnormal biochemical results was seen in elevated ALT (53.91\%) followed by elevated triglycerides (34.75\%). The prevalence of abnormal total cholesterol level was significantly higher $(\mathrm{p}=0.04)$ in the group of obese children compared to the severely obese children. The levels of total cholesterol were also statistically higher in the group of adolescents compared to preadolescents $(\mathrm{p}=0.02)$. An important number of obese patients $(2.5 \%)$ and even higher number of severely obese patients $(5.26 \%)$ had carbohydrate intolerance.

Conclusion: There was a significant elevation of ALT, total serum cholesterol and triglycerides in all study participants. High serum lipids and high hepatic enzymes (as introduction in non-alcoholic fatty liver disease) are alarming. Strikingly, there was carbohydrate intolerance in an important number of patients. Treatment and education of patients and parents is mandatory. Preventive measures in the society concerning childhood obesity are necessary.

Keywords: childhood obesity, hepatic enzymes, serum lipids

\section{INTRODUCTION}

Obesity is defined as an excess of adipose tissue accumulation to the level that could impair health. [1] Over the last few decades, obesity has been considered to be epidemic and reached pandemic proportions. The worldwide number of obese children and adolescents since 1980 has risen from 921 million up to the level of 2.1 billion, [2] while in 2016, 41 million children younger than 5 years were considered overweight or obese. [1] Some studies indicate 
that there is some evidence for stabilization and plateauing of pediatric obesity, but still confirms that its prevalence remains high. $[3,4,5]$ Despite the plateauing in childhood and adolescent obesity, the prevalence of severe obesity in this age group has also been shown to be increased. [6] Severe obesity affects between $4-6 \%$ of children in the United States of America and shows an increasing trend. [7]

Obesity in childhood and adolescence is associated with many metabolic and adverse longterm complications that reflect in adulthood. There is growing body of evidence suggesting that the degree of obesity also affects metabolic health of children and adolescents. Children and adolescents who were obese from childhood to adulthood were associated with increased risk of many metabolic abnormalities and type 2 diabetes mellitus, suggesting that obese individuals show unfavorable metabolic profile that is associated with high cardiovascular risk. [8] Moreover, children with high BMI have an increased risk for obesity later in adulthood. [9]

The degree of obesity also negatively impacts the metabolic profile of obese children. [10, $11,12]$ Further classifying pediatric obesity could be used as an effective tool for predicting comorbidities. [13] Children having severe obesity exhibit significantly more unfavorable cardio metabolic profile than children with obesity. [14] However, there is one study that came to unexpected results where that degree of obesity had no impact on the metabolic profile of severely obese adults. Even more, in this study, very severely obese adults had more favorable metabolic parameters than the severely obese group. [15]

This study aimed to investigate the metabolic laboratory parameters in children and adolescents with obesity and severe obesity.

\section{METHODS}

This cross-sectional study obtained data of various metabolic parameters from obese and severely obese children and included retrospective and prospective analysis of medical records of obese children and adolescents admitted at our hospital for regular obesity evaluation since the electronic database was available at the University Clinic of Child Diseases - Skopje. Patients' his- tories from November 2009 until July 2017 were evaluated. The study was conducted according to the Declaration of Helsinki and was approved by the Ethical Committee of the Faculty of Medicine of the University "Ss. Cyril and Methodius" Skopje, Macedonia.

\section{Study sample}

The study comprised of 158 obese children and adolescents (Table 1).

\section{Inclusion and Exclusion criteria}

Inclusion criteria for participant enrollment was obesity, as defined from the sex- and agespecific growth charts provided by the Centers of Disease Control and Prevention (CDC) - Body Mass Index $\geq 95$ th percentile. [16] Exclusion criteria were as follows: diabetes, congenital hyperlipidemia, long-term corticosteroid treatment, Cushing's disease and Cushing's syndrome.

\section{Obesity classification}

Children aged $<2$ years were considered obese if the weight for recumbent length was 97. $7^{\text {th }}$ percentile according to the World Health Organization (WHO) growth standards. [17] Obesity in children $>2$ years was classified according to the age- and sex- growth charts proposed by the Centers of Disease Control and Prevention, as $\mathrm{BMI} \geq 95$ th percentile for sex and age, [16] while severe obesity was defined as $120 \%$ of the 95 th percentile for age and sex. [7]

\section{Age groups}

Patients were further divided in two subgroups: preadolescents, aged 4-11 years and adolescents, aged $12-18$ years. [18]

\section{Clinical examinations}

All clinical examinations were performed by experienced pediatricians together with welltrained medical personal. Participants' body weight (to the nearest $0.1 \mathrm{~kg}$ ) and height (to the nearest $0.1 \mathrm{~cm}$ ) were measured barefoot with light clothing according to the standard procedures. In children aged $<2$ years, the recumbent length was measured to the nearest $\mathrm{cm}$. Body Mass Index was calculated according to the standard formula as weight (kilograms) divided by height (meters) squared. 


\section{OGTT test}

The oral glucose tolerance test was performed according to the recommendations of the WHO. The glucose load was $1.75 \mathrm{~g}$ of glucose per $\mathrm{kg}$ body weight up to a total of $75 \mathrm{~g}$ of glucose. Blood samples were obtained at 0 and 120 minutes for the measurement of glucose. [19]

\section{Laboratory analysis}

Venous blood samples were collected following standard procedures from the antecubital vein after overnight fasting of 10-12 hours. The samples were analyzed for concentrations of: plasma glucose, total serum cholesterol, serum triglycerides, serum alanine amino trasnferase (ALT) and serum aspartate aminotransferase (AST). Two hours after the performance of OGTT, blood samples were obtained and plasma glucose concentration was determined. All blood samples were analyzed in clinical chemistry analyzer ARCHITECT c4000 (Abbott Diagnostics).

\section{Definitions of abnormal values}

For defining abnormal laboratory parameters we followed the following criteria: for ALT according to Schwimmer et al. (2010), >25 U/L (boys) and $>22 \mathrm{U} / \mathrm{L}$ (girls); [20] AST, according to the American Academy of Pediatrics, $>80 \mathrm{U} / \mathrm{L}$ (boys and girls up to 24 months), $>40 \mathrm{U} / \mathrm{L}$ (boys older than 24 months) and $>35$ (girls older than 24 months); [21] for total cholesterol and triglycerides according to the Expert Panel Summary Report: total cholesterol (mg/dL), <170 (acceptable), 170199 (borderline high), $\geq 200$ (high); triglycerides - 0-9 years $(\mathrm{mg} / \mathrm{dL})<75$ (acceptable), 75-99 (borderline high), $\geq 100$ (high), and 10-19 years (mg/ dL) $<90$ (acceptable), 90-129 (borderline high), $>130$ (high). [22] Fasting plasma glucose according to the American Diabetes Association, $\geq 5.6$ but $<7 \mathrm{mmol} / \mathrm{L}$ (prediabetes), $\geq 7 \mathrm{mmol} / \mathrm{L}$ (diabetes). At two hours post oral glucose tolerance test: $\geq 7.8$ but $<11.1 \mathrm{mmol} / \mathrm{L}$ (prediabetes) and $\geq 11.1$ $\mathrm{mmol} / \mathrm{L}$ (diabetes). [23] Definitions of abnormal levels are presented in Table 1 .

\section{Statistical analysis}

Descriptive statistics are presented as frequencies and percentages for categorical data and mean \pm standard deviation for continuous data. Before data analysis Smirnov-Kolmogorov and Shapiro-Wilk normality tests were performed in order to examine the data distribution of the sam- ple size. For normally distributed data, comparison of the mean values was done using $\mathrm{T}$ test while the correlation was investigated using the Pearson correlation. Mann-Whitney U-test and Spearman rank correlation was used for data not normally distributed. The differences of distribution of abnormal metabolic parameters among study groups were examined using the Pearson Chi square test. Analysis was completed by using the statistical software package STATISTICA version 8.0. P values $<0.05$ were considered statistically significant.

\section{RESULTS}

Table 1 presents the adequate cohort size and the definition of abnormal levels for each laboratory parameter.

Table 1. Definition of abnormal levels of laboratory parameters and respective sample size for each study variable

\begin{tabular}{|c|c|c|c|c|}
\hline Variable & $\begin{array}{c}\text { No. of } \\
\text { Partic- } \\
\text { ipants } \\
\text { Evalu- } \\
\text { ated }\end{array}$ & $\begin{array}{c}\text { Mean } \pm \text { SD } \\
\text { (range) }\end{array}$ & $\begin{array}{c}\text { Age } \\
\text { (mean } \\
\pm \text { SD) }\end{array}$ & $\begin{array}{c}\text { Definition of } \\
\text { abnormal value }\end{array}$ \\
\hline $\begin{array}{c}\text { ALT } \\
(\mathrm{U} / \mathrm{L})\end{array}$ & 115 & $\begin{array}{c}29.66 \pm 17.55 \\
(9-93)\end{array}$ & $\begin{array}{c}10.42 \pm \\
3.11\end{array}$ & $\begin{array}{l}>25 \mathrm{U} / \mathrm{L} \text { (boys) } \\
>22 \mathrm{U} / \mathrm{L} \text { (girls) }\end{array}$ \\
\hline $\begin{array}{l}\text { AST } \\
(\mathrm{U} / \mathrm{L})\end{array}$ & 115 & $\begin{array}{c}24.45 \pm 11.23 \\
(7-93)\end{array}$ & $\begin{array}{c}10.42 \pm \\
3.11\end{array}$ & $\begin{array}{c}>80 \mathrm{U} / \mathrm{L}^{\dagger} \\
>40 \mathrm{U} / \mathrm{L} \text { (boys) }{ }^{\dagger \dagger} \\
>35 \mathrm{U} / \mathrm{L} \text { (girls) }{ }^{\dagger \dagger}\end{array}$ \\
\hline $\begin{array}{c}\mathrm{TC} \\
(\mathrm{mmol} / \mathrm{L})\end{array}$ & 141 & $\begin{array}{l}4.17 \pm 0.77 \\
(2.35-7.50)\end{array}$ & $\begin{array}{c}10.43 \pm \\
3.08\end{array}$ & $\geq 5.18^{\#}$ \\
\hline $\begin{array}{c}\mathrm{TG} \\
(\mathrm{mmol} / \mathrm{L})\end{array}$ & 141 & $\begin{array}{l}1.26 \pm 0.68 \\
(0.40-5.83)\end{array}$ & $\begin{array}{c}10.43 \pm \\
3.08\end{array}$ & $\begin{array}{c}0-9 \text { years }>1.13^{\#} \\
10-19 \text { years } \\
>1.469^{\#}\end{array}$ \\
\hline $\begin{array}{c}\text { FPG } \\
(\mathrm{mmol} / \mathrm{L})\end{array}$ & 141 & $\begin{array}{l}4.18 \pm 0.55 \\
(2.30-6.51)\end{array}$ & $\begin{array}{c}10.43 \pm \\
3.15\end{array}$ & $\geq 5.6 \mathrm{mmol} / \mathrm{L}$ \\
\hline $\begin{array}{c}2-\mathrm{h} \mathrm{G} \\
(\mathrm{mmol} / \mathrm{L})\end{array}$ & 134 & $\begin{array}{c}5.65 \pm 1.39 \\
(2.80-12.80)\end{array}$ & $\begin{array}{c}10.51 \pm \\
3.17\end{array}$ & $\geq 7.8 \mathrm{mmol} / \mathrm{L}$ \\
\hline
\end{tabular}

ALT, alanine aminotransferase; AST, aspartate aminotrrasferase; TC, total cholesterol; TG, triglycerides; FPG, fasting plasma glucose; 2-h G, plasma glucose two hours post the glucose load during the oral glucose tolerance test; "boys and girls up to 24 months; ${ }^{\dagger}$ older than 24 months; ${ }^{*}$ in order to convert $\mathrm{mg} / \mathrm{dL}$ to $\mathrm{mmol} / \mathrm{L}$ values of total cholesterol and triglycerides were multiplied by 0.0259 and 0.0113 , respectively.

Table 2 presents the descriptive statistics of patients admitted at the University Hospital for Child Diseases - Skopje, Macedonia. The final study sample consisted of 158 obese children and adolescents with mean age $10.43 \pm 3.11$. As shown 
in Table 2, the majority of study participants were considered severely obese $(69.92 \%)$. Higher percentage of boys was severely obese, although the difference between boys and girls was not significant $(70.73 \%$ boys, $68.42 \%$ girls). The group of preadolescents and adolescents consisted of different sample size (154 participants). The proportion of preadolescents (prepubertal) was also higher in boys, but there was not a statistically significant difference. The BMI was significantly higher in girls than in boys $(\mathrm{p}=0.02)$.

Table 3 shows biochemical laboratory measurements among children and adolescents participating in the study. The levels of ALT,
AST and plasma glucose two hours after the oral glucose tolerance test were higher in the severely obese group, while the levels of total cholesterol, triglycerides and fasting plasma glucose were higher in the obese study group. These differences were only significant for the total cholesterol. The levels of ALT and AST were also significantly higher in girls compared to boys. Other laboratory parameters showed no statistically significant differences. The level of total cholesterol was shown to be significantly higher in the age group $\geq 12$ years compared to the group aged 4-11 years.

Table 2. Descriptive statistics of patients enrolled in the study of metabolic profile among obese children and adolescents

\begin{tabular}{|c|c|c|c|c|}
\hline \multirow[t]{2}{*}{ Characteristics } & All $(n=158)$ & Boys $(n=82)$ & Girls $(n=76)$ & \multirow[t]{2}{*}{$p$-value } \\
\hline & n $(\%)$ or mean $\pm($ SD) & n $(\%)$ or mean $\pm(\mathrm{SD})$ & n $(\%)$ or mean $\pm($ SD) & \\
\hline Obesity class* & & & & $0.75^{1}$ \\
\hline Obese & $48(30.38)$ & $24(29.27)$ & $24(31.58)$ & \\
\hline Severely Obese & $110(69.92)$ & $58(70.73)$ & $52(68.42)$ & \\
\hline $\begin{array}{l}\text { Preadolescents } \\
\text { vs. adolescents } \\
(\mathrm{n}=154)^{*}\end{array}$ & & & & $0.11^{2}$ \\
\hline Preadolescents & $84(54.55)$ & $48(60.76)$ & $36(48.00)$ & \\
\hline Adolescents & $70(45.45)$ & $31(39.24)$ & $39(52.00)$ & \\
\hline Age (years) $)^{\dagger}$ & $10.43 \pm 3.11$ & $10.30 \pm 3.07$ & $10.57 \pm 3.18$ & 0.53 \\
\hline Weight $(\mathrm{kg})^{\dagger}$ & $73.74 \pm 23.66$ & $73.02 \pm 24.66$ & $74.51 \pm 22.67$ & 0.37 \\
\hline Height $(\mathrm{cm})^{\dagger}$ & $149.83 \pm 17.87$ & $150.17 \pm 19.53$ & $149.46 \pm 16.01$ & 0.66 \\
\hline BMI $\left(\mathrm{kg} / \mathrm{m}^{2}\right)^{\dagger \dagger}$ & $31.57 \pm 4.67$ & $30.75 \pm 3.97$ & $32.44 \pm 5.20$ & 0.02 \\
\hline
\end{tabular}

${ }^{*}$ Obtained from $\chi^{2}$ test for comparison of categorical variables;

Group comparison was examined using the Mann-Whitney U test for continuous data;

" Group comparison was examined using $t$ test for continuous data;

${ }^{1}$ Pearson $\chi^{2}=0.1, \mathrm{df}=1 ;{ }^{2}$ Pearson $\chi^{2}=2.53, \mathrm{df}=1$; BMI, Body Mass Index.

Table 3. Biochemical laboratory measurements of children and adolescents participating in the study by different study groups

\begin{tabular}{|c|c|c|c|c|c|c|}
\hline \multirow{2}{*}{$\begin{array}{c}\text { Analysis by obesity } \\
\text { class }\end{array}$} & \multirow{2}{*}{ Sample size } & \multicolumn{2}{|c|}{ Obese } & \multicolumn{2}{|c|}{ Severely obese } & \multirow{2}{*}{$p$-value* } \\
\hline & & Participants no. & Mean \pm SD & Participants no. & Mean \pm SD & \\
\hline $\operatorname{ALT}(\mathrm{U} / \mathrm{L})$ & 115 & 31 & $27.84 \pm 19.96$ & 84 & $30.33 \pm 16.66$ & 0.14 \\
\hline AST (U/L) & 115 & 31 & $23.32 \pm 7.61$ & 84 & $24.87 \pm 12.32$ & 0.69 \\
\hline $\mathrm{TC}(\mathrm{mmol} / \mathrm{L})$ & 141 & 44 & $4.36 \pm 0.73$ & 97 & $4.08 \pm 0.78$ & 0.04 \\
\hline TG (mmol/L) & 141 & 44 & $1.39 \pm 0.90$ & 97 & $1.20 \pm 0.54$ & 0.24 \\
\hline FPG (mmol/L) & 141 & 43 & $4.27 \pm 0.59$ & 98 & $4.14 \pm 0.53$ & 0.18 \\
\hline 2-h G (mmol/L) & 134 & 40 & $5.56 \pm 1.25$ & 94 & $5.68 \pm 1.45$ & 0.79 \\
\hline
\end{tabular}




\begin{tabular}{|c|c|c|c|c|c|c|}
\hline Analysis by gender & \multirow[b]{2}{*}{ Sample size } & \multicolumn{2}{|c|}{ Boys } & \multicolumn{2}{|c|}{ Girls } & \multirow[b]{2}{*}{$p$-value* } \\
\hline Variable & & Participants no. & Mean $\pm \mathrm{SD}$ & Participants no. & Mean $\pm \mathrm{SD}$ & \\
\hline $\operatorname{ALT}(\mathrm{U} / \mathrm{L})$ & 115 & 60 & $34.37 \pm 20.58$ & 55 & $24.53 \pm 11.66$ & 0.005 \\
\hline $\operatorname{AST}(\mathrm{U} / \mathrm{L})$ & 115 & 60 & $27.17 \pm 13.16$ & 55 & $21.49 \pm 7.75$ & 0.003 \\
\hline $\mathrm{TC}(\mathrm{mmol} / \mathrm{L})$ & 141 & 72 & $4.13 \pm 0.83$ & 69 & $4.21 \pm 0.71$ & 0.32 \\
\hline $\mathrm{TG}(\mathrm{mmol} / \mathrm{L})$ & 141 & 72 & $1.25 \pm 0.79$ & 69 & $1.27 \pm 0.53$ & 0.18 \\
\hline $\mathrm{FPG}(\mathrm{mmol} / \mathrm{L})$ & 141 & 72 & $4.20 \pm 0.65$ & 69 & $4.15 \pm 0.43$ & 0.93 \\
\hline 2-h G (mmol/L) & 134 & 70 & $5.65 \pm 1.46$ & 64 & $5.65 \pm 1.32$ & 0.83 \\
\hline $\begin{array}{l}\text { Analysis according } \\
\text { to age group }\end{array}$ & \multirow{2}{*}{ Sample size } & \multicolumn{2}{|c|}{ Preadolescents (4-11) } & \multicolumn{2}{|c|}{ Adolescents (12-18) } & p-value* \\
\hline Variable & & Participants no. & Mean \pm SD & Participants no. & Mean \pm SD & \\
\hline $\operatorname{ALT}(\mathrm{U} / \mathrm{L})$ & 113 & 62 & $29.58 \pm 17.66$ & 51 & $30.02 \pm 17.88$ & 0.24 \\
\hline $\operatorname{AST}(\mathrm{U} / \mathrm{L})$ & 113 & 62 & $25.53 \pm 11.85$ & 51 & $22.90 \pm 10.54$ & 0.07 \\
\hline $\mathrm{TC}(\mathrm{mmol} / \mathrm{L})$ & 138 & 77 & $4.05 \pm 0.76$ & 61 & $4.35 \pm 0.76$ & 0.02 \\
\hline $\mathrm{TG}(\mathrm{mmol} / \mathrm{L})$ & 138 & 77 & $1.21 \pm 0.60$ & 61 & $1.34 \pm 0.77$ & 0.16 \\
\hline $\mathrm{FPG}(\mathrm{mmol} / \mathrm{L})$ & 138 & 76 & $4.14 \pm 0.44$ & 62 & $4.23 \pm 0.67$ & 0.52 \\
\hline 2-h G (mmol/L) & 131 & 70 & $5.60 \pm 1.17$ & 61 & $5.79 \pm 1.59$ & 0.86 \\
\hline
\end{tabular}

* Group comparison was examined using Mann-Whitney U test for continuous data; ALT, alanine aminotransferase; AST, aspartate aminotransferase; TC, total cholesterol; TG, triglycerides; FPG, fasting plasma glucose; 2-h G, plasma glucose two hours post the glucose load during the oral glucose tolerance test. $\mathrm{x}$.

Table 4 shows the distribution of abnormal laboratory parameters among different study groups. The prevalence of abnormal total cholesterol level was significantly higher in the group of obese children. Abnormal levels of ALT were higher in severely obese children, but this difference was not statistically significant. Abnor- mal levels of fasting plasma glucose were also seen more frequently in boys compared to girls $(p=0.03)$. Comparison of the distribution of abnormal biochemical parameters between the two age groups (preadolescents, $<12$ and adolescents $\geq 12$ years) did not reveal any statistical significance.

Table 4. Distribution (\%) of abnormal laboratory parameters between different study groups

\begin{tabular}{|c|c|c|c|c|c|c|}
\hline \multirow{2}{*}{ Obesity class } & \multirow{2}{*}{$\begin{array}{c}\mathbf{A L T} \\
(\mathrm{U} / \mathrm{L})\end{array}$} & AST & \multirow{2}{*}{$\mathbf{T C}(\mathrm{mmol} / \mathrm{L})$} & \multirow{2}{*}{$\mathbf{T G}(\mathrm{mmol} / \mathrm{L})$} & \multirow{2}{*}{ FPG $(\mathrm{mmol} / \mathrm{L})$} & \multirow{2}{*}{$\begin{array}{c}\mathbf{2 - h} \mathbf{G} \\
(\mathrm{mmol} / \mathrm{L})\end{array}$} \\
\hline & & $(\mathrm{U} / \mathrm{L})$ & & & & \\
\hline Obesity & 41.94 & 6.45 & 18.18 & 40.91 & 4.65 & 2.50 \\
\hline Severe obesity & 58.33 & 4.76 & 6.19 & 31.96 & 3.06 & 5.26 \\
\hline$p$-value* & $0.12^{1}$ & $0.72^{2}$ & $0.04^{3}$ & $0.64^{4}$ & $0.68^{5}$ & $0.72^{6}$ \\
\hline \multicolumn{7}{|l|}{ Gender } \\
\hline Boys & 58.33 & 6.67 & 9.72 & 31.94 & 6.94 & 2.82 \\
\hline Girls & 49.09 & 3.64 & 10.14 & 37.68 & 0 & 6.25 \\
\hline$p$-value* & $0.32^{7}$ & $0.47^{8}$ & $0.75^{9}$ & $0.51^{10}$ & $\mathbf{0 . 0 3}^{11}$ & $0.22^{12}$ \\
\hline \multicolumn{7}{|l|}{$\begin{array}{l}\text { Preadolescents vs. } \\
\text { adolescents }\end{array}$} \\
\hline Preadolescents & 54.84 & 4.84 & 9.09 & 37.66 & 1.32 & 1.43 \\
\hline Adolescents & 52.94 & 5.88 & 11.48 & 32.79 & 6.45 & 8.06 \\
\hline$p$-value* & $0.84^{13}$ & $0.81^{14}$ & $0.66^{15}$ & $0.49^{16}$ & $0.11^{17}$ & $0.18^{18}$ \\
\hline
\end{tabular}

* Obtained from $\chi^{2}$ test for comparison of categorical variables;

${ }^{1}$ Pearson $\chi^{2}=2.45 ; \mathrm{df}=1 ; 2$ Pearson $\chi^{2}=0.13 ; \mathrm{df}=1 ;{ }^{3}$ Pearson $\chi^{2}=6.37 ; \mathrm{df}=2 ;{ }^{4}$ Pearson $\chi^{2}=1.14 ; \mathrm{df}=2 ;{ }^{5}$ Pearson $\chi^{2}=0.22 ; \mathrm{df}=1 ;{ }^{6}$ Pearson $\chi^{2}=0.67 ; \mathrm{df}=2 ;{ }^{7}$ Pearson $\chi^{2}=0.99 ; \mathrm{df}=1 ;{ }^{8}$ Pearson $\chi^{2}=0.53 ; \mathrm{df}=1 ;{ }^{9}$ Pearson $\chi^{2}=0.58 ; \mathrm{df}=2$; ${ }^{10}$ Pearson $\chi^{2}=1.34 ; \mathrm{df}=2 ;{ }^{11}$ Pearson $\chi^{2}=4.97 ; \mathrm{df}=1 ;{ }^{12}$ Pearson $\chi^{2}=3.07 ; \mathrm{df}=2 ;{ }^{13}$ Pearson $\chi^{2}=0.04 ; \mathrm{df}=1 ;{ }^{14}$ Pearson $\chi^{2}=0.06 ; \mathrm{df}=1 ;{ }^{15}$ Pearson $\chi^{2}=0.83 ; \mathrm{df}=2 ;{ }^{16}$ Pearson $\chi^{2}=1.44 ; \mathrm{df}=2 ;{ }^{17}$ Pearson $\chi^{2}=2.58 ; \mathrm{df}=1 ;{ }^{18}$ Pearson $\chi^{2}=3.47 ; \mathrm{df}$ = 2; ALT, alanine aminotransferase; AST, aspartate aminotrrasferase; TC, total cholesterol; TG, triglycerides; FPG, fasting plasma glucose; 2-h G, plasma glucose two hours post the glucose load during the oral glucose tolerance test. 
Correlation analyses are shown in Table 5. There were no statistically significant correlations between BMI values and laboratory parameters.

Table 5. Correlation analysis of Body Mass Index and laboratory parameters

\begin{tabular}{|l|c|c|c|}
\hline Variable & $\mathbf{N}$ & $\mathbf{R}^{\dagger}$ & $\boldsymbol{p}$-value* \\
\hline ALT (U/L) & 115 & 0.08 & 0.37 \\
\hline AST (U/L) & 115 & -0.17 & 0.07 \\
\hline TC (mmol/L) & 141 & 0.01 & 0.95 \\
\hline TG (mmol/L) & 141 & 0.07 & 0.43 \\
\hline FPG (mmol/L) & 141 & -0.06 & 0.46 \\
\hline 2-h G (mmol/L) & 134 & 0.11 & 0.22 \\
\hline
\end{tabular}

†Correlation between Body Mass Index (BMI) and laboratory parameters in obese children and adolescents presented as correlation coefficient $\mathrm{R}$ with $\mathrm{p}$-values. *Correlation was examined using Spearman's correlation; ALT, alanine aminotransferase; AST, aspartate aminotrrasferase; TC, total cholesterol; TG, triglycerides; FPG, fasting plasma glucose; 2-h G, plasma glucose two hours post the glucose load during the oral glucose tolerance test

\section{DISCUSSION}

Overall, almost $70 \%$ of obese children included in our study have been considered severely obese $(>120 \%$ of the 95 th percentile). Severe obesity was common in both, boys and girls, in our study sample.

Slightly more boys were considered severely obese than girls. These results are consistent with the results of other studies. [24, 25] According to the results of a large cross-sectional study, remarkable differences were noted between males and females, supporting further classification of severe obesity, especially in boys. [11] Also, their results show that obese male participants had higher prevalence of abnormal triglyceride level, glycosilated hemoglobin level and systolic blood pressure than female participants. However, there is one study reporting obesity to be higher in girls. [26]

Dyslipidemia is highly associated with pediatric obesity. [8, 27, 28] Childhood obesity has been shown to be associated with metabolic syndrome, too. [29] Our results indicate that obese children and adolescents have significantly higher total cholesterol levels when compared to severely obese. Also, the prevalence of abnormal total cholesterol was found to be significantly higher in the obese group when compared to the severely obese group. Our findings are consistent with the results of Salvatore et al., where the prevalence of the total and LDL cholesterol did not trend with the severity of obesity, indicating the limited usefulness of these two parameters. Similarly to what we have found, abnormal total cholesterol was highest among children within obesity class I. Moreover, in this study the prevalence of total cholesterol was also higher in overweight compared to obese children with a distribution of $66.7 \%$ and $47.7 \%$, respectively. [13] Also, another study has shown that total cholesterol did not differ among different classes of severely obese and non - obese controls. [30] Contrary to our results, a study conducted on 463 obese children and adolescents did not reveal statistical significance considering the level of total cholesterol according to the severity of obesity. This same study found statistically higher triglycerides levels in severely obese compared to moderately obese children. [31] However, one large cross-sectional study that investigated cardiometabolic risks in severely obese children and young adults showed that the prevalence of abnormal total cholesterol levels did increase significantly with the severity of obesity. [11] A cross-sectional study evaluating cardiometabolic profile of 854 high school students found hypertension in $11 \%$, impaired glucose metabolism in $9 \%$, hypertriglyceridemia in $9 \%$ and hypercholesterolemia in $5 \%$ of the study population, advocating the need for lifestyle changes. [32] Another nationwide prospective surveillance study has shown that at least one cardiovascular risk factor was present in $67 \%$ of children and adolescents with severe obesity whereas hypertension was the most frequently found, 56\%. [24]

Participants aged $\geq 12$ years have higher prevalence of abnormal total cholesterol compared to participants $<12$ years, although the difference was not significant. In addition, adolescents also have significantly higher total cholesterol levels. A study that investigated the high cardiovascular risk in severely obese children found that cardiovascular risk factors were more present in boys aged $\geq 12$ years. [24] In our study, higher prevalence of elevated ALT, and high triglycerides was more common among preadolescents, while abnormal total cholesterol, fasting plasma glucose and plasma glucose two hours after OGTT performance, were higher among adolescents. 
The most common abnormal laboratory parameters in the whole study group were high ALT levels (53.91\%) followed by high triglycerides $(34.75 \%)$. This is in accordance with the high prevalence of high triglycerides $(11.2 \%)$ in the study of Makkes et al. [12]

Children with obesity tend to have increased fasting glucose, insulin and insulin resistance. [33] It is of notice that in our study group an important number of obese patients $(2.5 \%)$ and even higher number of severely obese patients $(5.26 \%)$ had carbohydrate intolerance. The prevalence of abnormal fasting plasma glucose in our study sample was significantly higher in obese boys than in obese girls. Other studies reported these difference among obese males and females to be not significant. [34, 35] However, our results show that the prevalence of abnormal plasma glucose 2 hours after the performance of oral glucose tolerance test did not reveal significant differences between boys and girls. Another larger cross-sectional study found significantly higher prevalence of elevated blood glucose in participants with severe obesity. [11] According to our study, the difference in the fasting blood glucose levels as well as the prevalence of abnormal blood glucose levels between children with obesity and severe obesity was not significant. Our results are in line with the findings by Rank et al., where the comparison of glucose levels as well as the prevalence of elevated glucose between children with moderate and severe obesity showed no statistically significant difference. [31] However, differences in glucose levels were found to be significant between normal weight and overweight children. [36] Fasting glucose was not significantly higher in the severe obesity group with less than 3 metabolic risk factors compared to non-obese subjects, but showed statistical difference in the severe obesity group with more than 3 metabolic risk factors. [30]

Non-alcoholic fatty liver disease (NAFLD) is the most common pediatric liver disease, but also one of the possible complications secondary to obesity. [37] One study showed that $10 \%$ of children with obesity have elevated ALT levels. [38] In our study, 53.91\% of obese children had an abnormal level of ALT. Schwimmer et al., recently pointed out that ALT levels for screening NAFLD in obese children were set too high. Using the newly derived thresholds, the sensitivity for NAFLD detection has increased significantly [20]. The use of ALT as a screening tool is encouraged in the early detection of NAFLD in children and adolescents with obesity. [39] Children and adolescents with severe obesity from our study showed higher prevalence of abnormal ALT compared to the children and adolescents with obesity, although this was not statistically significant. This finding is in accordance with the findings of Salvatore et al., where children in obesity class II and III had prevalence of abnormal ALT two times higher than children in obesity class I. [13] Also, it has been shown that severely obese children that have more than 3 metabolic risk factors have significantly higher values of ALT. [30] The ALT level in our study was significantly higher in obese boys than in obese girls. This gender specific difference could be explained by the existence of different cut off values for ALT in boys and girls. The prevalence of abnormal ALT levels in both, obese and severely obese children and adolescents in our study was remarkably high. A more comprehensive study on the gender specific association of ALT with various metabolic parameters found higher proportion of obese children with elevated ALT levels, particularly in boys. Boys with higher levels of ALT have been associated with higher waist circumference. This is again due to the normally low levels of adiponectin in boys, which is, on the other hand, associated with higher waist circumference. [40]

Studies on larger cohort size, follow-up on obesity patients are needed to further advance the knowledge on obesity and consequences in children and adolescents.

\section{CONCLUSIONS}

There was a significant elevation of ALT, triglycerides and total serum cholesterol in all study participants. High serum lipids and high hepatic enzymes (as introduction in non-alcoholic fatty liver disease) are alarming. Obese children showed to have significantly higher levels and prevalence of abnormal total cholesterol compared to severely obese children. Strikingly, there was carbohydrate intolerance in an important number of patients. Treatment and education of patients and parents is mandatory. Preventive measures in the society concerning childhood obesity are necessary. 


\section{REFERENCES}

1. World Health Organization (WHO). Obesity and overweight fact sheet, http://www.who.int/mediacentre/factsheets/fs $311 / \mathrm{en} /$ (2017, accessed 9 November 2017).

2. $\mathrm{Ng} \mathrm{M}$, Fleming $\mathrm{T}$, Robinson $\mathrm{M}$, et al. Global, regional and national prevalence of overweight and obesity in children and adults 1980-2013: A systematic analysis. Lancet. 2014; 384(9945): 766-781.

3. Wabitsch M, Moss A, Kromeyer-Hauschild K. Unexpected plateauing of childhood obesity rates in developed countries. BMC Medicine. 2014; 12: 17.

4. Blüher S, Meigen C, Gausche R, et al. Age-specific stabilization in obesity prevalence in German children: a cross-sectional study from 1999 to 2008. Int J Pediatr Obes. 2011; 6(2-2): e199206.

5. Ahluwalia N, Dalmasso P, Rasmussen M, et al. Trends in overweight prevalence among 11-, 13and 15-year-olds in 25 countries in Europe, Canada and USA from 2002 to 2010. Eur J Public Health. 2015; 25(Suppl 2): 28-32.

6. Skinner AC, Skelton JA. Prevalence and trends in obesity and severe obesity among children in the United States, 1999-2012. JAMA Pediatr. 2014; 168(6): 561-6.

7. Kelly AS, Barlow SE, Rao G, et al. Severe obesity in children and adolescents: identification, associated health risks, and treatment approaches: a scientific statement from the American Heart Association. Circulation. 2013; 128(15): 1689-712.

8. Juonala M, Magnussen CG, Berenson GS, et al. Childhood adiposity, adult adiposity, and cardiovascular risk factors. N Engl J Med. 2011; 365(20): 1876-85.

9. Singh AS, Mulder C, Twisk JW, et al. Tracking of childhood overweight into adulthood: a systematic review of the literature. Obes Rev. 2008; 9(5): 474-88.
10. Weiss R, Kaufman FR. Metabolic complications of childhood obesity: identifying and mitigating the risk. Diabetes Care. 2008; 31(Suppl 2): S310-6.

11. Skinner AC, Perrin EM, Moss LA, et al. Cardiometabolic Risks and Severity of Obesity in Children and Young Adults. N Engl J Med. 2015; 373(14): 1307-17.

12. Makkes S, Renders CM, Bosmans JE, et al. Cardiometabolic risk factors and quality of life in severely obese children and adolescents in the Netherlands. BMC Pediatrics. 2013; 13: 62.

13. Salvatore D, Satnick A, Abell R, et al. The prevalence of abnormal metabolic parameters in obese and overweight children. J Parenter Enteral Nutr. 2014; 38(7): 852-5.

14. Li L, Pérez A, Wu LT, et al. Cardiometabolic Risk Factors among Severely Obese Children and Adolescents in the United States, 1999-2012. Child Obes. 2016; 12(1): 12-9.

15. Wolf AM, Buffington C, Beisiegel U. Comparison of metabolic risk factors between severely and very severely obese patients. Obesity. 2006; 14(12): 2177-83.

16. Barlow SE. Expert committee recommendations regarding the prevention, assessment, and treatment of child and adolescent overweight and obesity: summary report. Pediatrics. 2007; 120(Suppl 4): S164-92.

17. Krebs NF, Himes JH, Jacobson D, et al. Assessment of child and adolescent overweight and obesity. Pediatrics. 2007; 120(Suppl 4): S193-S228.

18. Patel DA, Srinivasan SR, Chen W, et al. Serum Alanine Aminotransferase and Its Association with Metabolic Syndrome in Children: The Bogalusa Heart Study. Metabolic Syndrome and Related Disorders. 2011; 9(3): 211-216.

19. Alberti KG, Zimmet PZ. Definition, Diagnosis and Classification of Diabetes Mellitus and its Complications Part 1 : Diagnosis and Classification of Diabetes Mellitus Provisional Report of a WHO Consultation. 1998; 15(7): 539-553.

20. Schwimmer JB, Dunn W, Norman GJ, et al. SAFETY study: Alanine aminotransferase cutoff values are set too high for reliable detection of 
pediatric chronic liver disease. Gastroenterology. 2010; 138(4): 1357-1364.e2.

21. Soghier L, Pham K, Rooney S. Reference Range values for Pediatric Care. Elk Grove Village, IL: American Academy of Pediatrics 2014; 70.

22. Expert Panel on Integrated Guidelines for Cardiovascular Health and Risk Reduction in Children and Adolescents, National Heart, Lung, and Blood Institute. Expert Panel on Integrated Guidelines for Cardiovascular Health and Risk Reduction in Children and Adolescents: summary report. Pediatrics. 2011; 128(Suppl 5): S213-S256.

23. American Diabetes Association. Classification and Diagnosis of Diabetes. Diabetes Care. 2016; 39(Suppl 1): S13-22.

24. van Emmerik NM, Renders CM, van de Veer M, et al. High cardiovascular risk in severely obese young children and adolescents. Arch Dis Child. 2012; 97(9): 818-21.

25. Freedman DS, Mei Z, Srinivasan SR, et al. Cardiovascular risk factors and excess adiposity among overweight children and adolescents: the Bogalusa Heart Study. J Pediatr. 2007; 150(1): 12-17.e2.

26. Schönbeck Y, Talma H, van Dommelen $P$, et al. Increase in Prevalence of Overweight in Dutch Children and Adolescents: A Comparison of Nationwide Growth Studies in 1980, 1997 and 2009. PLoS ONE. 2011; 6(11): e27608.

27. Cook S, Kavey REW. Dyslipidemia and Pediatric Obesity. Pediatric clinics of North America. 2011; 58(6): 1363-1373.

28. Smoak CG, Burke GL, Webber LS, et al. Relation of obesity to clustering of cardiovascular disease risk factors in children and young adults. The Bogalusa Heart Study. Am J Epidemiol. 1987; 125(3): 364-72.

29. Chen F, Wang Y, Shan X, et al. Association between Childhood Obesity and Metabolic Syndrome: Evidence from a Large Sample of Chinese Children and Adolescents. PLoS ONE. 2012; 7(10): e47380.

30. Codoñer-Franch P, Murria-Estal R, Tortajada-Girbés $M$, et al. New factors of cardiometa- bolic risk in severely obese children: influence of pubertal status. Nutr Hosp. 2010; 25(5): 845-51.

31. Rank M, Siegrist M, Wilks DC, et al. The cardio-metabolic risk of moderate and severe obesity in children and adolescents. J Pediatr. 2013; 163(1): 137-42.

32. Rocha T, Rocha E, Alves AC. Cardiovascular risk profile of high school students: a cross-sectional study. Rev Port Cardiol. 2014; 33(9): 525-34.

33. Maffeis C, Pinelli L, Brambilla P. Fasting plasma glucose (FPG) and the risk of impaired glucose tolerance in obese children and adolescents. Obesity. 2010; 18(7): 1437-42.

34. Valerio G, Maffeis C, Balsamo A, et al. Severe Obesity and Cardiometabolic Risk in Children: Comparison from Two International Classification Systems. PLoS ONE. 2013; 8(12): e83793.

35. Ling JCY, Mohamed MNA, Jalaludin MY, et al. Determinants of High Fasting Insulin and Insulin Resistance Among Overweight/Obese Adolescents. Scientific Reports. 2016; 6: 36270.

36. Hrafnkelsson H, Magnusson KT, Sigurdsson EL, et al. Association of BMI and fasting insulin with cardiovascular disease risk factors in seven-yearold Icelandic children. Scandinavian Journal of Primary Health Care. 2009; 27(3): 186-191.

37. Lavine JE, Schwimmer JB. Nonalcoholic fatty liver disease in the pediatric population. Clin Liver Dis. 2004; 8(3): 549-58.

38. Strauss RS, Barlow SE, Dietz WH. Prevalence of abnormal serum aminotransferase values in overweight and obese adolescents. J Pediatr. 2000; 136(6): 727-33.

39. Styne DM, Arslanian SA, Connor EL, et al. Pediatric Obesity-Assessment, Treatment, and Prevention: An Endocrine Society Clinical Practice Guideline. J Clin Endocrinol Metab. 2017; 102(3): 709-757.

40. Di Bonito P, Sanguigno E, Di Fraia T, et al. Association of elevated serum alanine aminotransferase with metabolic factors in obese children: sex-related analysis. Metabolism. 2009; 58(3): 368-72. 


\title{
Резиме
}

ПАРАМЕТРИ НА МЕТАБОЛНИЧКИОТ СИНДРОМ КАЈ ОБЕЗНИТЕ ДЕЦА И АДОЛЕСЦЕНТИ Марко Костовски ${ }^{1}$, Зоран Гучев ${ }^{1}$, Велибор Тасиќ ${ }^{1}$, Момир Поленаковиќ ${ }^{2}$

\author{
${ }^{1}$ Медицински факултет, Универзитет „Св. Кирил и Методиј“, Скопје, Република Македонија \\ ${ }^{2}$ Македонска академија на науките и уметностите, Скопје, Република Македонија
}

Вовед: Обезноста претставува најчесто хронично метаболно заболување кај децата и адолесцентите. Значајно е дека обезноста достигна речиси епидемиски размери и се смета за глобален проблем на современото време.

Цели: Целта на оваа студија беше да ја испита дистрибуцијата и разликите на одредени метаболни лабораториски параметри, кај децата и адолесцентите со обезност и тешка форма на обезност.

Испитаници и методи: Оваа студија на пресек вклучува 158 (82 момчиња, 76 девојчиња) обезни деца и адолесценти на возраст од 0 до 17 години (10,43 $\pm 3,11$ години). Обезноста е дефинирана според критериумите на Центрите за контрола и превенција на болестите преку специфични табели на раст за полот и возраста за индексот на телесната маса (BMI) $\geq 95$ перцентили. Тешката обезност беше дефинирана како 120\% од 95-тиот перцентил за возраста и полот, соодветно. Испитаниците беа подложени на детален медицински преглед и биохемиски испитувања, кои опфаќаа збир метаболички параметри: ALT, AST, серумски триглицериди на гладно, тотален холестерол, плазма концентрација на гликоза на гладно и концетрација на гликоза во плазма во состав на оралниот тест за толеранција на гликоза.

Резултати: Кај мнозинството од испитаниците беше констатирана тешка форма на обезност $(69,92 \%)$. Највисока застапеност на абнормални биохемиски лабораториски параметри беше забележана кај вредностите за $\operatorname{ALT}(53,91 \%)$ и триглицеридите (34,75\%). Дистрибуцијата на абнормалните нивоа на вкупен холестерол во крвта беа сигнификантно повисоки $(\mathrm{p}=0,04)$ во групата на обезни деца во споредба со оние со тешка обезност. Вредностите на вкупниот холестерол беа значајно повисоки кај адолесцентите во споредба со преадолесцентите (p = 0,02). Значаен број обезни пациенти $(2,5 \%)$ и уште поголем број пациенти со тешка форма на обезност $(5,26 \%)$ имаа интолеранција на јаглехидрати.

Заклучок: Кај сите испитаници беше забележана значајна елевација на ALT, триглицеридите и вкупниот холестерол. Високите вредности на серумски липиди и високите хепатални ензими (како почеток на неалкохолната црнодробна болест) се алармантни. Значајно е што кај значителен број пациенти беше забележана јаглехидратна интолеранција. Третманот и едукацијата на пациентите и родителите е задолжителна. Неопходно е преземање превентивни мерки за справување со обезноста во детството од страна на општеството.

Клучни зборови: обезност во детството, хепатални ензими, серумски липиди 